University of Wollongong

Research Online

Faculty of Engineering and Information

Faculty of Engineering and Information

Sciences - Papers: Part B

Sciences

2019

The rapid chemically induced corrosion of concrete sewers at high $\mathrm{H} 2 \mathrm{~S}$ concentration

\author{
Xuan Li \\ University of Queensland \\ Liza O'Moore \\ University of Queensland \\ Yarong Song \\ University of Queensland \\ Philp Bond \\ University of Queensland \\ Zhiguo Yuan \\ University of Queensland
}

See next page for additional authors

Follow this and additional works at: https://ro.uow.edu.au/eispapers1

Part of the Engineering Commons, and the Science and Technology Studies Commons

Research Online is the open access institutional repository for the University of Wollongong. For further information contact the UOW Library: research-pubs@uow.edu.au 


\title{
The rapid chemically induced corrosion of concrete sewers at high $\mathrm{H} 2 \mathrm{~S}$ concentration
}

\begin{abstract}
Concrete corrosion in sewers is primarily caused by $\mathrm{H} 2 \mathrm{~S}$ in sewer atmosphere. $\mathrm{H} 2 \mathrm{~S}$ concentration can vary from several ppm to hundreds of ppm in real sewers. Our understanding of sewer corrosion has increased dramatically in recent years, however, there is limited knowledge of the concrete corrosion at high $\mathrm{H} 2 \mathrm{~S}$ levels. This study examined the corrosion development in sewers with high H2S concentrations. Fresh concrete coupons, manufactured according to sewer pipe standards, were exposed to corrosive conditions in a pilot-scale gravity sewer system with gaseous $\mathrm{H} 2 \mathrm{~S}$ at $1100 \pm 100 \mathrm{ppm}$. The corrosion process was continuously monitored by measuring the surface $\mathrm{pH}$, corrosion product composition, corrosion loss and the microbial community. The surface $\mathrm{pH}$ of concrete was reduced from $10.5 \pm 0.3$ to $3.1 \pm 0.5$ within 20 days and this coincided with a rapid corrosion rate of $3.5 \pm 0.3 \mathrm{~mm}$ year -1 . Microbial community analysis based on 16S rRNA gene sequencing indicated the absence of sulfide-oxidizing microorganisms in the corrosion layer. The chemical analysis of corrosion products supported the reaction of cement with sulfuric acid formed by the chemical oxidation of H2S. The rapid corrosion of concrete in the gravity pipe was confirmed to be caused by the chemical oxidation of hydrogen sulfide at high concentrations. This is in contrast to the conventional knowledge that is focused on microbially induced corrosion. This first-ever systematic investigation shows that chemically induced oxidation of $\mathrm{H} 2 \mathrm{~S}$ leads to the rapid corrosion of new concrete sewers within a few weeks. These findings contribute novel understanding of in-sewer corrosion processes and hold profound implications for sewer operation and corrosion management.
\end{abstract}

\section{Keywords}

h2sconcentration, induced, corrosion, concrete, rapid, sewers, chemically, high

\section{Disciplines}

Engineering | Science and Technology Studies

\section{Publication Details}

Li, X., O'Moore, L., Song, Y., Bond, P. L., Yuan, Z., Wilkie, S., Hanzic, L. \& Jiang, G. (2019). The rapid

chemically induced corrosion of concrete sewers at high H2S concentration. Water Research, 162 95-104.

\section{Authors}

Xuan Li, Liza O'Moore, Yarong Song, Philp Bond, Zhiguo Yuan, Simeon Wilkie, Lucija Hanzic, and Guangming Jiang 


\section{The Rapid Chemically Induced Corrosion of Concrete Sewers at High $\mathrm{H}_{2} \mathrm{~S}$}

\section{Concentration}

3

4 Xuan Li ${ }^{\text {a }}$, Liza O'Moore ${ }^{\text {b }}$, Yarong Song ${ }^{\text {a }}$, Philp. L. Bond ${ }^{\text {a }}$, Zhiguo Yuan ${ }^{\text {a }}$, Simeon Wilkie ${ }^{\text {a, }}$

$5 \quad$ c, Lucija Hanzic ${ }^{\text {b }}$, Guangming Jiang a, d, *

6 a Advanced Water Management Centre, The University of Queensland, Australia

$7 \quad \mathrm{~b}$ School of Civil Engineering, The University of Queensland, Australia

$8 \quad{ }^{\mathrm{c}}$ Division of Civil Engineering, University of Dundee, Scotland

9 d School of Civil, Mining and Environmental Engineering, University of Wollongong,

10 Australia

11 XL:xuan.li@awmc.uq.edu.au; LO: 1.omoore@uq.edu.au; YS: yarong.song@awmc.uq.edu.au; PB:

12 phil.bond@uq.edu.au; SW: s.z.wilkie@dundee.ac.uk; LH: 1.hanzic@uq.edu.au; ZY:

13 z.yuan@awmc.uq.edu.au

* Corresponding author. E-mail: g.jiang@awmc.uq.edu.au; gjiang@uow.edu.au; Tel.: +61 431573255.

17 Highlights:

- The first report of chemically induced concrete corrosion in sewers

- High concentration of $\mathrm{H}_{2} \mathrm{~S}$ can be chemically oxidized into sulfuric acid at sewer crown

- Sulfide oxidizing microorganisms were not participating in the rapid corrosion 


\section{Abstract:}

23 Concrete corrosion in sewers is primarily caused by $\mathrm{H}_{2} \mathrm{~S}$ in sewer atmosphere. $\mathrm{H}_{2} \mathrm{~S}$ concentration can vary from several ppm to hundreds of ppm in real sewers. Our understanding of sewer corrosion has increased dramatically in recent years, however, there is limited knowledge of the concrete corrosion at high $\mathrm{H}_{2} \mathrm{~S}$ levels. This study examined the corrosion development in sewers with high $\mathrm{H}_{2} \mathrm{~S}$ concentrations. Fresh concrete coupons, manufactured according to sewer pipe standards, were exposed to corrosive conditions in a pilot-scale gravity sewer system with gaseous $\mathrm{H}_{2} \mathrm{~S}$ at $1100 \pm 100 \mathrm{ppm}$. The corrosion process was continuously monitored by measuring the surface $\mathrm{pH}$, corrosion product composition, corrosion loss and the microbial community. The surface $\mathrm{pH}$ of concrete was reduced from $10.5 \pm 0.3$ to $3.1 \pm 0.5$ within 20 days and this coincided with a rapid corrosion rate of $3.5 \pm 0.3 \mathrm{~mm}_{\text {year }}{ }^{-1}$. Microbial community analysis based on 16S rRNA gene sequencing indicated the absence of sulfideoxidizing microorganisms in the corrosion layer. The chemical analysis of corrosion products supported the reaction of cement with sulfuric acid formed by the chemical oxidation of $\mathrm{H}_{2} \mathrm{~S}$. The rapid corrosion of concrete in the gravity pipe was confirmed to be caused by the chemical oxidation of hydrogen sulfide at high concentrations. This is in contrast to the conventional knowledge that is focused on microbially induced corrosion. This first-ever systematic investigation shows that chemically induced oxidation of $\mathrm{H}_{2} \mathrm{~S}$ leads to the rapid corrosion of new concrete sewers within a few weeks. These findings contribute novel understanding of insewer corrosion processes and hold profound implications for sewer operation and corrosion management.

44 Key words: Sewer, Corrosion, Concrete, Hydrogen sulfide, Chemically Induced Corrosion 


\section{Introduction}

47 As one of the most critical components of the urban infrastructure in modern societies, sewer networks collect and transport sewage to treatment plants, preventing human exposure to unhygienic sewage and related sewage-borne diseases. The prevalence of concrete corrosion weakens the structural strength of sewers and leads to early collapse of pipes (Zhang et al. 2008). The damage inflicted on many sewer networks and the cost of preventive measures is a significant world-wide economic problem (Alexander et al. 2013, Jiang et al. 2016a, Jiang et al. 2015a). In addition to enormous sewer remediation expenditure, the structural failure also poses potential issues of odor emission and public safety (Jiang et al. 2017).

The corrosion of concrete pipes is mainly a result of hydrogen sulfide $\left(\mathrm{H}_{2} \mathrm{~S}\right) . \mathrm{H}_{2} \mathrm{~S}$ is formed by sulfate-reducing bacteria (SRB) in the anaerobic sewer biofilms/sediments. From the sewage, $\mathrm{H}_{2} \mathrm{~S}$ is emitted to the sewer air, part of which is absorbed/adsorbed into the moisture layer on the concrete walls exposed to air, here it is oxidized to sulfuric acid and causes corrosion (Li et al. 2017). $\mathrm{H}_{2} \mathrm{~S}$ is ubiquitous in sewer systems, although the concentrations differ temporally and spatially from a few ppm to several hundred ppm (Jiang et al. 2014, Wells and Melchers 2015).

Sewer concrete corrosion is a relatively slow process that may take years or decades to occur (Joseph et al. 2012). A three-stage concept proposed by Islander et al. (1991) is widely adopted to describe the corrosion development. In the initiation stage, the surface $\mathrm{pH}$ of the concrete is reduced from c.a.13 to c.a. 9 by carbonation and $\mathrm{H}_{2} \mathrm{~S}$ dissolution. This leads to the later stages where the $\mathrm{pH}$ of the concrete surface is conducive for microorganisms to colonize. Depending on the $\mathrm{pH}$, both neutrophilic and acidophilic sulfide oxidizing microorganisms will biologically oxidize sulfur compounds to sulfuric acid. The reaction between cementitious material and sulfuric acid produces corrosion products like gypsum $\left(\mathrm{CaSO}_{4}\right)$, resulting in the structural 
weakening of concrete sewers (Davis et al. 1998, Harrison Jr 1984, Islander et al. 1991, Nica et al. 2000, Parker 1947). Since the biological oxidation rate is much higher than the chemical oxidation rate, microbial induced sulfuric acid production is regarded as the main cause for the sewer concrete corrosion (Hvitved-Jacobsen et al. 2013).

Current strategies for controlling sewer corrosion are targeted to: (1) prevent $\mathrm{H}_{2} \mathrm{~S}$ production and its partition from the sewer liquid phase through the dosing of antimicrobials, iron salts, $\mathrm{pH}$ elevating compounds and oxidants to the sewage; (2) reduce the $\mathrm{H}_{2} \mathrm{~S}$ concentration in sewer air through forced ventilation; (3) applying surface treatment on concrete sewers (Jiang et al. 2015a). Corrosion resistant materials like antimicrobials, silver-loaded zeolite, and polymers coatings are widely used to mitigate the corrosion of sewers (Berndt 2011, De Muynck et al. 2009, Haile and Nakhla 2010, Sun et al. 2015).

With the increased use of corrosion-resistant materials and surface treatments in sewers, instead of reacting with concrete, the $\mathrm{H}_{2} \mathrm{~S}$ in sewer air can accumulate to very high concentrations. In real sewers, $\mathrm{H}_{2} \mathrm{~S}$ concentrations of over $800 \mathrm{ppm}$ are observed in a gravity pipe (Wells and Melchers 2015). Furthermore, various factors such as high wastewater sulfate concentrations, and extended hydraulic retention times can lead to high sewer $\mathrm{H}_{2} \mathrm{~S}$ concentrations (Lahav et al. 2004, Sharma et al. 2008).

To date, microbially induced sulfuric acid generation from $\mathrm{H}_{2} \mathrm{~S}$ is considered as the major contributing cause of sewer mass loss and structure failure. However, elevated $\mathrm{H}_{2} \mathrm{~S}$ concentrations in sewers might result in changed corrosion mechanisms and processes. In

90 particular, the chemical oxidation rate of sulfide would be greatly increased, due to the 91 reaction's $\mathrm{n}^{\text {th }}$ order kinetics $(\mathrm{n}=0.90-1.38)($ Chen and Morris 1972 , Haaning Nielsen et al. 92 2004). Considering the relative slow growth of sulfide oxidizing microorganisms and the potential toxicity of $\mathrm{H}_{2} \mathrm{~S}$, the chemical oxidation could play a more important role than the microbial oxidation to the corrosion under high sewer $\mathrm{H}_{2} \mathrm{~S}$ conditions. 
The kinetics of the chemical oxidation of $\mathrm{H}_{2} \mathrm{~S}$ on the concrete surface has received limited attention (Æsøy et al. 2002). The pathway of microbial oxidation of $\mathrm{H}_{2} \mathrm{~S}$ has been studied previously and elemental sulfur, thiosulfate, and sulfate are reported as the possible oxidation products/intermediates (Li et al. 2017, Nica et al. 2000, Parker 1945a). Very few studies have investigated the concrete corrosion induced by chemical sulfide oxidation. $\mathrm{H}_{2} \mathrm{~S}$ absorption and oxidation on corroding concrete surfaces was examined at peak concentrations around 1000 ppm (Vollertsen et al. 2008). Here they reported that the $\mathrm{H}_{2} \mathrm{~S}$ oxidation rate was as high as 1 $\mathrm{mg} \mathrm{S} \mathrm{m}^{-2} \mathrm{~s}^{-1}$ and it followed the $\mathrm{n}^{\text {th }}$ order kinetics $(\mathrm{n}=0.45-0.75)$. However, the study did not differentiate whether the rapid sulfide oxidation was chemical or biological. Another study has investigated the abiotic and biotic oxidation of hydrogen sulfide in in an acidic solution containing active concrete corrosion products $\{$ Jensen, $2009 \# 246\}$. In this study, the abiotic oxidation was much slower compared with the biotic oxidation. But the oxidation products of sulfide were not examined for abiotic oxidation and the abiotic kinetics were limited to acidic solution containing corrosion layer.

Unlike in concrete systems, numerous investigations regarding the chemical sulfide oxidation

110 have been carried out in water, where $\mathrm{pH}$ shows significant impact on the oxidation process.

111 In acidic solutions, the chemical oxidation rate is slow at $\mathrm{pH}<6$ and once the $\mathrm{pH}$ increases 112 through 7 to 11 , the oxidation rate increases greatly (Chen and Morris 1972). On concrete

113 surface, the condensation water layer provides the essential medium for the chemical and 114 biological sulfide oxidation reactions. It is thus possible that the newly manufactured concrete 115 sewers, that will have high surface $\mathrm{pH}$, are susceptible to the corrosion caused by chemical 116 oxidation of sulfide at high $\mathrm{H}_{2} \mathrm{~S}$ concentrations.

117 Thus, at high $\mathrm{H}_{2} \mathrm{~S}$ concentrations, the three-stage concept of corrosion development for newly 118 manufactured concrete sewers, it is likely very important to consider the contribution of 119 chemical sulfide oxidation prior to the occurrence and contribution of microbially induced 
120 corrosion. To our knowledge, no systematic investigation has been conducted to monitor the

121 corrosion under high $\mathrm{H}_{2} \mathrm{~S}$ concentrations and to determine the corrosion behavior, including

122 corrosion rate and products, of newly constructed concrete sewers.

123 In this study, the development of corrosion was studied in detail on concrete coupons exposed

124 in a pilot sewer system with high $\mathrm{H}_{2} \mathrm{~S}$ concentrations $(1100 \pm 100 \mathrm{ppm})$. The corrosion rate,

125 processes and products were determined by measuring the changes of concrete properties such

126 as surface $\mathrm{pH}$, sulfide oxidation products, microbial communities on the surface and

127 mineralogy. Batch tests were then performed to determine the sulfide oxidation kinetics in the

128 presence of fresh concrete powder or corrosion products. The knowledge obtained regarding

129 the chemically induced corrosion of concrete has important practical implications for sewer

130 operation, maintenance and management.

\section{2. Materials and methods}

\subsection{Concrete mix design and property}

133 Concrete coupons were prepared according to the mix design (Table 1) in compliance with the

134 Australian standard (Standard AS2972) (2010). The cement (General Blended cement, Cement

135 Australia Builders Cement) used nominally contains up to $25 \%$ fly ash. Four types of 136 aggregates were used, including crushed aggregate $(10 \mathrm{~mm})$ with nominal maximum size of

$13710 \mathrm{~mm}$; crushed manufactured sand (MS); natural river sand (RS) and natural fine sand (FS).

138 For the better workability and moderate slump retention, super plasticizer (MasterGlenium 139 SKY 8700, BASF, Australia) was also added (Table 1).

Table 1. Concrete coupon mix design and properties

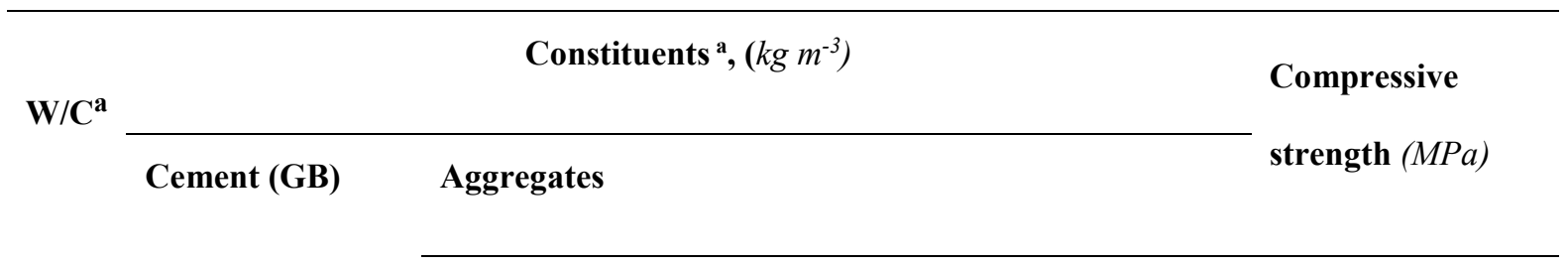


$\begin{array}{llllll}10 \mathrm{~mm} & \text { MS } & \text { RS } & \text { FS } & \text { TOTAL } & \begin{array}{l}\text { Super } \\ \text { plasticiser }\end{array}\end{array}$

\begin{tabular}{lllllllll}
\hline 0.40 & 420 & 753 & 376 & 471 & 282 & 1882 & 4.2 & 63
\end{tabular}

${ }^{\text {a }}$ Constituents are given as mass needed to form $1 \mathrm{~m}^{3}$ of concrete

${ }^{\mathrm{b}} \mathrm{W} / \mathrm{C}$ : water/cement mass ratio

143 Properties of the concrete including compressive strength, density, shrinkage, slump and 144 apparent volume of permeable voids were measured in accordance with the AS 1012.9

145 (Australian Standard 1986) for the requirements of sewer pipe (Table 1, Table S1). The acid 146 neutralization capacity (ANC) was determined by titrating a given mass of the concrete against

147 various quantities of $0.4 \mathrm{M}$ sulfuric acid using the methods adapted from (Sun et al. 2014) and 148 as described in section 1.2-SI.

149 Concrete coupons were cast with dimensions of $100 \mathrm{~mm}$ (length) $\times 70 \mathrm{~mm}$ (width) $\times 50 \mathrm{~mm}$

150 (thickness). The coupons were cured in moist air for $24 \mathrm{~h}$ and then cured in lime-saturated 151 water for 28 days. After curing, the coupons were dried in an oven (Thermotec 2000, Contherm) 152 at $60^{\circ} \mathrm{C}$ for 3 days to achieve similar and stable initial water content (Joseph et al., 2010). Two 153 dried coupons were then embedded as a pair in a stainless steel frame, providing a reference 154 point for determining the change in thickness due to corrosion (Jiang et al., 2014). And then coupons was enclosed with one surface exposed for each coupon using epoxy (FGI R180 epoxy $156 \&$ H180 hardener).

158 The pilot-scale gravity sewer pipe (225 mm ID PVC pipes), located in the Luggage Point

159 Wastewater Treatment Plant (WWTP, Brisbane, Australia) (Figure 1), had a total workable 160 length of 300 meters with an overall slope at $0.56 \%$. Raw wastewater of the WWTP influent 
161 was fed to the gravity pipe continuously at $100 \mathrm{~L} \mathrm{~min}^{-1}$. The wastewater contained dissolved

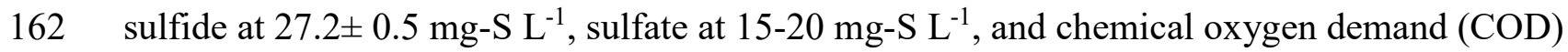
163 at $550-620 \mathrm{mg} \mathrm{L}^{-1}$. The pilot sewer system was controlled by a programmable logic controller 164 (PLC), and the operation state was manipulated using the Lab-View (Lab-View 2014, Real 165 Time) (Song et al. 2018a).
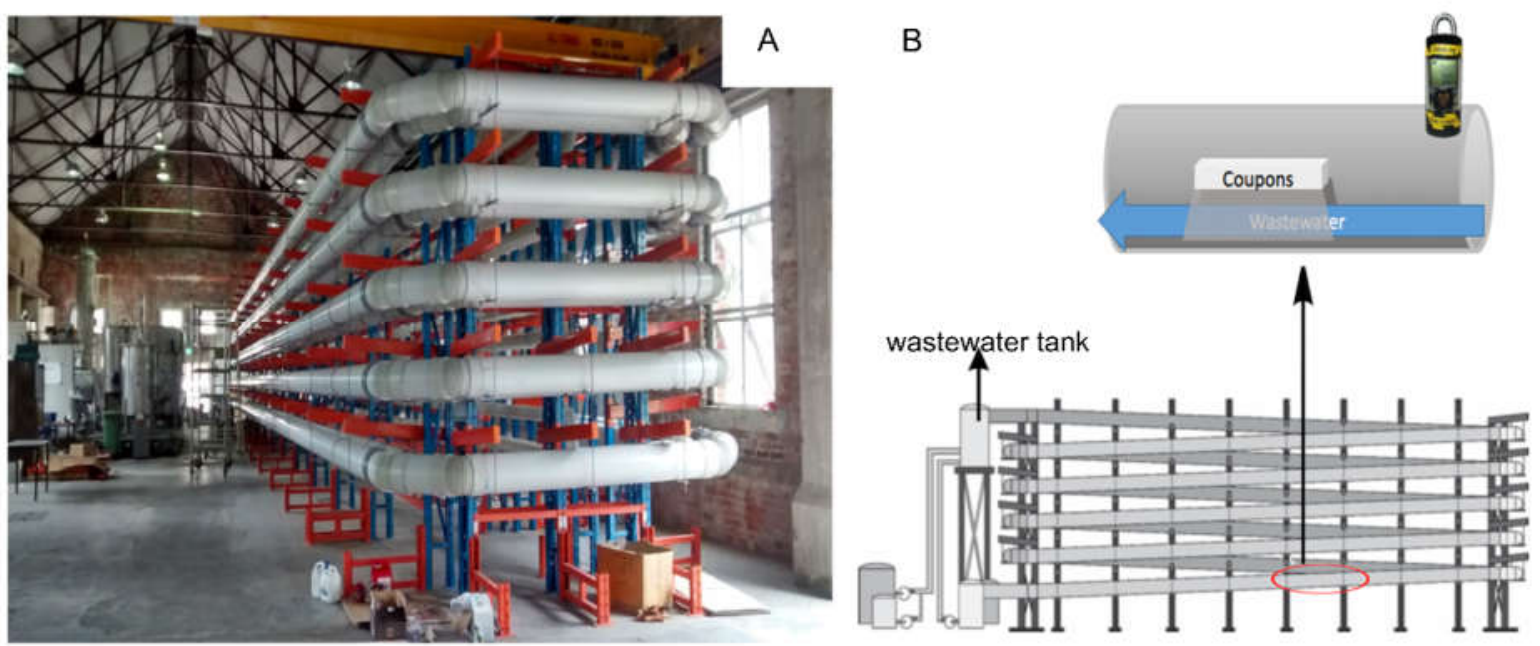

167 Figure 1. Photo of the pilot-scale gravity sewer system (A) and a schematic diagram of the pipe and the coupon installment for corrosion tests (B)

169 Four concrete coupons, enclosed in stainless-steel frames, were installed in the gas-phase of 170 the gravity sewer pipe, at about 250 meters away from the sewer inlet. The coupons were 171 placed on a plastic shelf inside the pipe so that the exposed surface was facing downwards, approximately $110 \mathrm{~mm}$ above the sewage level (Figure 1). This coupon arrangement simulated the sewer pipe crown, a location which is reported to be highly susceptible to corrosion damage

174 (Islander et al. 1991). A $\mathrm{H}_{2} \mathrm{~S}$ sensor (App-Tek OdaLog ${ }^{\circledR}$ Logger L2, detection range of 0-2000 $175 \mathrm{ppm}$ ) was employed for the continuous monitoring of gaseous $\mathrm{H}_{2} \mathrm{~S}$ and temperature in the pipe 176 at the coupon location. The relative humidity (RH) was measured weekly using a hand-held 177 humidity meter (HM70, Vaisala, Australia). After 20 days of exposure the four concrete 
178 coupons were retrieved for detailed chemical and biological analysis as described in the

179 following sections.

181 To determine sulfide oxidation rates (SOR), sulfide uptake rates (SUR) of two coupons under 500-1500 ppm $\mathrm{H}_{2} \mathrm{~S}$ were measured after 20 days' exposure in the sewer pipe using the method described in Sun et al. (2014). Briefly, coupons retrieved from the pilot sewer were stored in a chamber with $100 \%$ humidity until placed into the $\mathrm{H}_{2} \mathrm{~S}$ uptake reactor where the relative humidity was controlled at $100 \%$. To measure the SUR of each target concentration (i.e. $C_{i}$, ppm), $\mathrm{H}_{2} \mathrm{~S}$ gas was generated in a bottle and injected into the reactor to achieve a gaseous concentration $20 \mathrm{ppm}$ higher than the target concentration (i.e. $C_{i}+20$, ppm). The $\mathrm{H}_{2} \mathrm{~S}$ level in the reactor was then monitored continuously using a $\mathrm{H}_{2} \mathrm{~S}$ detector (App-Tek OdaLog® Logger L2, detection range of 0-2000 ppm). The average SUR of the coupon at each target level was calculated from 3 to 5 replicate measurements using the monitored $\mathrm{H}_{2} \mathrm{~S}$ profiles (Sun et al., 2014). $\mathrm{H}_{2} \mathrm{~S}$ uptake data of the concrete coupons were determined in the presence of either air $\left(S U R_{A i r}\right)$ or nitrogen gas to exclude oxidation reactions $\left(S U R_{\text {Nitrogen }}\right)$. Based on these two SUR measurements, the sulfide oxidation rate (SOR) of a concrete coupon was defined as:

$$
S O R=S U R_{\text {Air }}-S U R_{\text {Nitrogen }}
$$

195 To determine the chemical oxidation rate of sulfide, the surface of two coupons were sprayed with $50 \mathrm{ml} \mathrm{70 \%} \mathrm{ethanol} \mathrm{and} \mathrm{then} \mathrm{left} \mathrm{to} \mathrm{dry} \mathrm{in} \mathrm{a} \mathrm{laminar} \mathrm{flow} \mathrm{sterile} \mathrm{hood} \mathrm{for} 2$ hours (Gu et al. 1998). The sterilized samples were then equilibrated with $100 \%$ humidity until a constant weight and then the SOR of the sterilized coupons was measured in the reactor as described above using a $\mathrm{H}_{2} \mathrm{~S}$ detector (App-Tek OdaLog® Logger L2, detection range of 0-200 ppm). 
201 The concrete surface $\mathrm{pH}$ of each coupon was determined by a flat surface $\mathrm{pH}$ electrode 202 (RapidRH $^{\circledR}$ potable pH kit, Wagner) (Sun et al., 2014). Four independent measurements at 203 different locations on the same coupon were used to calculate the average value.

204 The corrosion products on the surface of the exposed concrete coupons were then sub-sampled 205 for the analysis of sulfur compounds and microbial communities. For soluble sulfate 206 measurement, samples from a known surface area (4 independent locations) of each coupon 207 was scraped using a clean scalpel blade, dispersed into sulfide anti-oxidant buffer solution and 208 then measured using ion chromatography (Dionex ICS-2000)(Keller-Lehmann et al. 2006). For 209 elemental sulfur analysis, corrosion products collected from known surface area (4 independent 210 locations) were treated to convert elemental sulfur to thiosulfate, which was then determined 211 using ion chromatography (Dionex ICS-2000) (Jiang et al. 2009)

212 For DNA extraction, in order to get sufficient amount of sample, all the corrosion products, except used for sulfur compounds measurements, from four coupons were collected with a sterile surgical scalpel into a sterile $50 \mathrm{~mL}$ polypropylene falcon tube. The products were mixed, separated into duplicate samples and stored at $4{ }^{\circ} \mathrm{C}$ for less than $24 \mathrm{~h}$. Wastewater samples

216 were taken directly from the gravity pipe through sampling ports and stored at $4{ }^{\circ} \mathrm{C}$ for less

217 than $24 \mathrm{~h}$. The cells were separated from the corrosion products using a sucrose density gradient and DNA of the corrosion products and wastewater samples were extracted using the Fast

219 DNA $^{\mathrm{TM}}$ SPIN Kit for Soil (MP Biomedicals, CA, USA), as previously described (Jiang et al. 2016b). To perform 16S rRNA gene amplicon sequencing (Illumina),extracted DNA samples were provided to the Australia Center for Ecogenomics (ACE, Brisbane, Australia). The extracted 16S rRNA gene was amplified using the universal primer set $926 \mathrm{~F}\left(5^{\prime}-\right.$ AAACTYAAAKGAATTGACGG-3') and 1392R (5'-ACGGGCGGTGTGTRC-3'). The resulting PCR amplicons were purified using Agencourt AMPure XP beads (Beckman Coulter). 
Master Mix. The indexed amplicons were pooled together in equimolar concentrations and sequenced on MiSeq Sequencing System (Illumina) at ACE according to manufacturer's protocol.

230 Raw sequencing data were quality-filtered and demultiplexed using Trimmomatic, with poorquality sequences trimmed and removed. Subsequently, high-quality sequences at $97 \%$ similarity were clustered into operational taxonomic units (OTUs) using QIIME with default parameters, and representative OTU sequences were taxonomically BLASTed against the Greengenes 16S rRNA database. Finally, an OTU table consisting of the taxonomic classification and OTU representative sequences was produced.

236 To examine the chemistry and mineralogy of corrosion products formed on the concrete surface, small slices of exposed surface from each coupon (four in total) were carefully removed using a chisel, and dried in a vacuum oven (SEMSA OVEN 718) at $60{ }^{\circ} \mathrm{C}$ for $8 \mathrm{~h}$. The dried samples were then coated twice by a carbon coater (Quorum Q150T, UK), following the three heavy-burst model to obtain the carbon thickness of 30-40 nm. Coated samples were analyzed by the scanning electron microscopy (SEM) (JEOL JSM-6610, America) equipped with a detector (Oxford 50mm2 X-Max SDD x-ray) that enables simultaneous imaging and elemental analysis at high count rates with $125 \mathrm{eV}$ energy resolutions. The EDAX software (EDAX, AMETEK Inc) was utilized, at a frame resolution of $1024 \times 800$, with a dwell time of $200 \mathrm{~s} /$ frame, to collect 16 frames for each region of interest. The locations for spot analyses were not random, but chosen by examining the BSE (Backscattered electron) image, which was typically used to identify the boundaries of mineral phases (Song et al. 2018b).

248 After all the measurements mentioned above, the exposed surfaces of concrete coupons were washed using a high-pressure washer (Karcher K 5.20 M). The corrosion loss from the surface 
250 of each coupon was calculated based on the point mesh generated before and after exposure, using the photogrammetry approach (Jiang et al. 2015b, Wells et al. 2009).

\subsection{Batch tests: sulfide oxidation in the presence of concrete and corrosion products}

253 Batch tests were performed to determine the oxidation of hydrogen sulfide by oxygen in the presence of crushed powder from fresh concrete or corrosion products based on a modified method (Jensen et al. 2011). The batch tests were conducted in a glass reactor with $800 \mathrm{~mL}$ working volume at $24 \pm 0.5{ }^{\circ} \mathrm{C}$ (Figure S1). A pH sensor ( $\mathrm{pH} 150$, Oakton) and a dissolved oxygen (DO) sensor (LDO101, HQ40d, Hach) were mounted to the reactor and sealed with Teflon tape (Oxygen tape, Unasco Pty Ltd, Sydney, Australia). The solution was mixed at 100 rpm using a magnetic stirrer (Heidolph MR3000). A $50 \mathrm{~mL}$ syringe filled with the testing solution was used as a sample replacer to avoid headspace or negative pressure inside the reactor during sampling.

262 For fresh concrete powder, samples cut from the center of new concrete were disaggregated in an agate mill, then the aggregate free material was crushed to $<0.5 \mathrm{~mm}$ particles and then mixed together with the aggregates collected from disaggregation process. Corrosion products were collected using a sterile surgical scalpel from a corroding concrete coupon, which was partially submerged in wastewater in the pilot-scale gravity pipe (Figure 1) for one month. The corrosion products were autoclaved at $120^{\circ} \mathrm{C}$ for 20 minutes, and then cool down to $20^{\circ} \mathrm{C}$. For each test, either crushed fresh concrete powders $(20 \mathrm{~g})$ or autoclaved corrosion products $(10 \mathrm{~g})$ were transferred into the reactor with aerated milli-Q water.

Duplicate tests were carried out with no headspace in the reactor. At the beginning of each test,

271 the sulfide stock solution (about $300 \mathrm{mg}-\mathrm{S} \mathrm{L}^{-1}$ ) was prepared using $\mathrm{Na}_{2} \mathrm{~S} \cdot 9 \mathrm{H}_{2} \mathrm{O}$. The sulfide

272 was added to the reactor to achieve 5.0-6.5 $\mathrm{mg}^{-\mathrm{S} \mathrm{L}^{-1}}$, which corresponded to an equilibrium concentration of gaseous $\mathrm{H}_{2} \mathrm{~S}$ at 400-1000 ppm (pH 2-10) (Jensen et al. 2011). Liquid samples 
274 were taken at 15 minute intervals during the first hour and then every 1-hour over 4 hours for

275 the analysis of inorganic sulfur compounds using ion chromatography (Dionex ICS-

276 2000)(Keller-Lehmann et al. 2006).

\section{3. Results and discussion}

\subsection{Corrosion of concrete coupons exposed in the gravity sewer}

3.1.1 Visual inspection, surface $\mathrm{pH}$ and corrosion rate

280 During the exposure period, the gaseous $\mathrm{H}_{2} \mathrm{~S}$ concentration inside the pipe was at $1100 \pm 100$

$281 \mathrm{ppm}$, the temperature was $21.5 \pm 2.4^{\circ} \mathrm{C}$, and the relative humidity was $95.7 \pm 3.0 \%$. This level

282 of $\mathrm{H}_{2} \mathrm{~S}$ inside the pipe represented high level hot spots that occur in sewers. The high level also

283 facilitated the observation of measurable corrosion within a reasonable timeframe (i.e.

284 exposure time of several weeks).

285 From visual inspection, before exposure, the grayish surface of all four coupons was smooth

286 and firm (Figure 2). After 20 days, the color of entire surface became darker and obvious

287 corrosion products were observed at the edge of coupons (Figure 2). The corrosion products

288 were a light yellow color, expansive and loose. This is similar to typical corrosion products

289 formed due to microbial induced corrosion (Cayford 2012). The middle part of each coupon

290 was still sound with some dark spots observed from visual inspection. Likely the darks spots

291 were attributed to the leaching of ferruginous components of aggregates (Jana and Lewis 2005). 

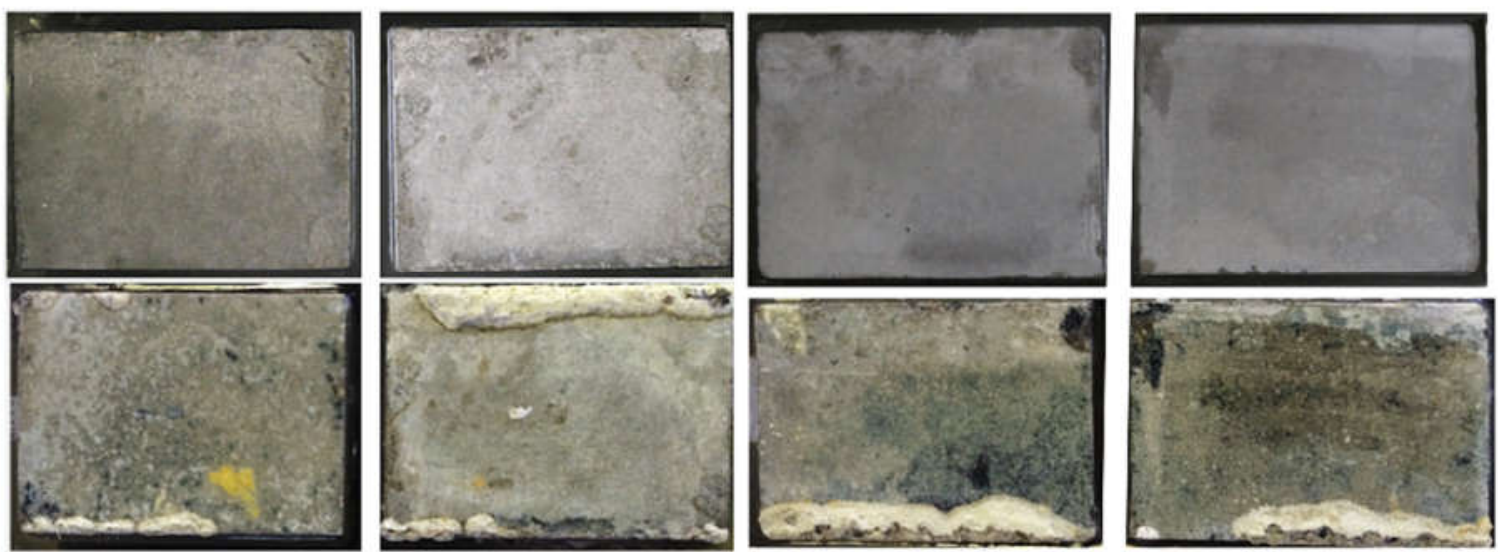

292

293 Figure 2. The surface conditions of the four concrete coupons before exposure (the first row), and after 20-days exposure (the second row).

Regional differences regarding $\mathrm{pH}$ was also observed on these coupons. The surface $\mathrm{pH}$ of coupons reduced from $10.5 \pm 0.3$ to $3.1 \pm 0.5$ at the edge and to $7.7 \pm 0.1$ in the middle parts after 20 days of exposure in the pipe. Surface $\mathrm{pH}$ is usually regarded as a good indicator of corrosion development and mass loss of concrete, as the alkalinity of the exposed concrete surface is consumed by direct or indirect reaction with $\mathrm{H}_{2} \mathrm{~S}$ in the sewer atmosphere. In a real sewer with $423 \mathrm{ppm}$ of $\mathrm{H}_{2} \mathrm{~S}$, the surface $\mathrm{pH}$ dropped from c.a. 10 to c.a. 7 in 6 months then further reduced to c.a. 4 in 20 months (Wells and Melchers 2015). Another lab study found that the surface pH was reduced from c.a. 10 to c.a. 7 and c.a. 4 in 6 months and 24 months exposure to 50 ppm of $\mathrm{H}_{2} \mathrm{~S}$, respectively (Jiang et al. 2015b). In comparison, the reduction of surface $\mathrm{pH}$ on both the middle and edge parts of the concrete coupons were much faster in this study. The $\mathrm{pH}$ reduction of concrete would eventually lead to the loss of concrete (Islander et al. 1991).

307 The average corrosion rate was determined from the four coupons as $3.5 \pm 0.3 \mathrm{~mm}^{-1} \mathrm{rear}^{-1}$ during 308 the 20 day exposure. Consistent with the $\mathrm{pH}$ and visual inspection, the corrosion rate is not uniform on the surface of each coupon. The corrosion on about $40-60 \%$ area of each coupon was observed to be insignificant (Figure 3). Whereas, several peaks of higher corrosion rates 
311 on less than $10 \%$ area of each coupon, were observed at around $9 \mathrm{~mm} \mathrm{year}^{-1}, 2-5 \mathrm{~mm} \mathrm{year}^{-1}$, 312 around $7 \mathrm{~mm}_{\text {year }}^{-1}$ and around $5 \mathrm{~mm}$ year $^{-1}$ for coupon I, II, III and IV, respectively (Figure

313 3). These higher corrosion rates were observed on areas along the edges of the coupons. As a 314 combination of cement, water, aggregates and other admixtures, concrete is not a homogenous 315 material. The structure of concrete around the edge is likely to be less sound due to the density 316 gradient of cement and aggregates, in comparison to the middle parts of the coupons. 317 Additionally, areas along the coupon edges on the surface were likely subjected to corrosion 318 attack from both the exposure surface and from the sides of exposure surfaces.

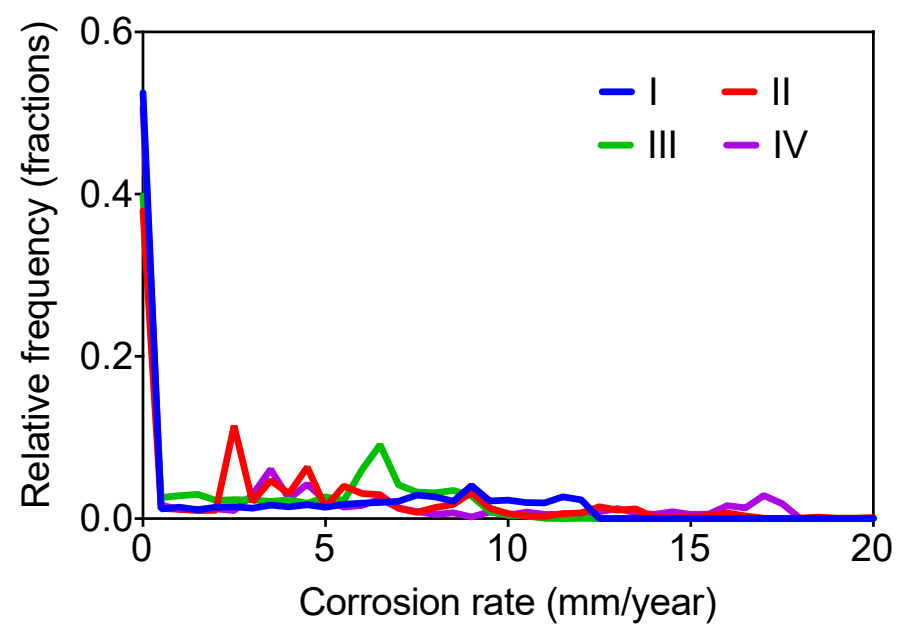

320 Figure 3. Relative frequency distribution of corrosion rates on the exposed surface of the four coupons (I, II, III and IV)

The average corrosion rate observed was similar to the rates detected on pipes subjected to corrosion in the USA, and higher than the rate of a sewer pipe with 12 years exposure, that is reportedly due to microbial induced corrosion (Zhang et al. 2008, Mori et al. 1991). The coupons used in this study were produced from fly ash blended concrete. Fly ash blended concretes are reported to be resistant to sulfide-oxidizing bacteria and have lower corrosion rates $\left.\left(1.0-1.3 \mathrm{~mm} \mathrm{year}^{-1}\right)\right)$. The corrosion rate detected in this study, especially on the coupon edge areas, was higher than that previously reported for fly ash blended concrete and for most 
sewer corrosion studies (Zhang et al. 2008, Mori et al. 1991). Furthermore, in studies of microbial induced concrete corrosion, the corrosion rates are usually reported after an initiation period. The initiation of corrosion on new concrete was conventionally considered as a slow process that takes several years or decades (Joseph et al. 2012). For example, corrosion loss was only observed after 12-months exposure in a real sewer with $\mathrm{H}_{2} \mathrm{~S}$ concentrations as high as $423 \mathrm{ppm}$ and after 34-months exposure in a laboratory corrosion chamber with $50 \mathrm{ppm} \mathrm{H}_{2} \mathrm{~S}$ (Jiang et al. 2015b, Wells and Melchers 2015). The fast corrosion that developed within 20 days in this study was different from all the previous reports.

The visual inspections, $\mathrm{pH}$ reduction and the determined corrosion rates confirmed the rapid development of corrosion on the coupon surface. This differs to what is previously reported and this rapid corrosion was very likely due to the extremely high concentration of $\mathrm{H}_{2} \mathrm{~S}$, which facilitated the chemical oxidation of sulfide.

\subsubsection{Corrosion product characteristics}

The microstructure analysis using SEM revealed considerable mineralogical changes on the coupon surface. Angular crystal formations were observed to be sulfur-containing corrosion products (Figure 4A, Figure S2) (Cayford 2012). These corrosion products were either loosely scattered on fly ash (region 1, Figure 4A) (Kutchko and Kim 2006), or piled up on a cement matrix (region 2 and 3, Figure 4A). Hexagonal formations (region 3, Figure 4A) and a collection of amorphous particles (region 2, Figure 4A) were observed, and these were typical of hydration products of cement, cement-calcium hydroxide, and calcium silicate hydrate (Franus et al. 2015). Lesser amounts of those hydration products were observed in comparison to corrosion products, which suggests that alkalinity loss occurred due to the corrosion process.

352 Similar microstructure was observed for all these four coupons (i.e. coupon I, II, III and IV) 

of microbes was found in the corrosion layer (Figure 4A, Figure S2).
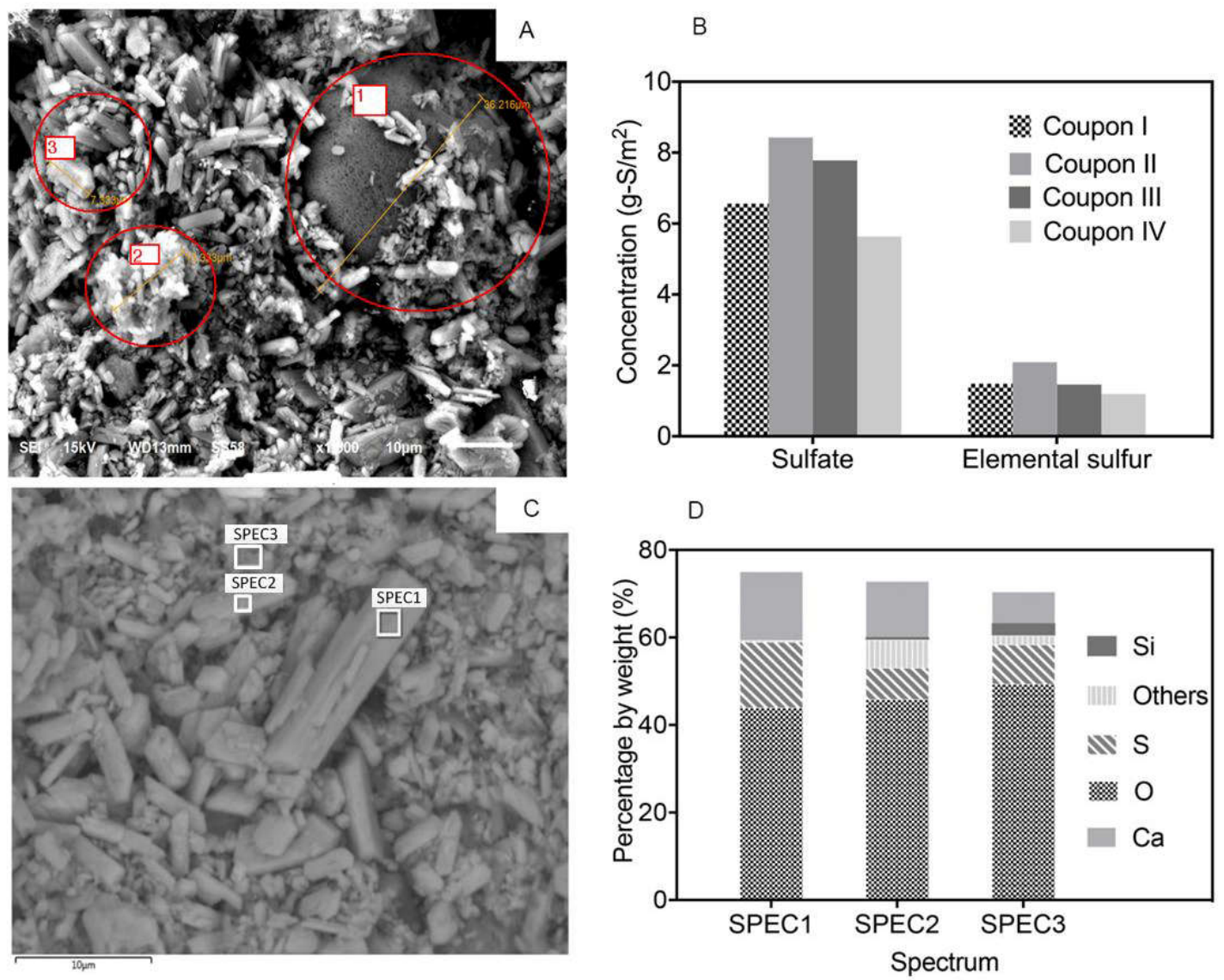

356

357 Figure 4. A SEM image of corrosion products on the surface of coupon I after the 20-day exposure in

358 the pilot gravity sewer pipe (A), sulfur species in the corrosion products (B), BSE image indicating the

359 regions on the coupon I surface selected for EDS analysis, shown as SPEC 1, 2 and 3 (C), and the

360 percentage of elements by weight, except the coating material, of SPEC 1, 2 and 3 (D)

362 Based on the different regional brightness in BSE images (Figure 4C, Figure S2), the major 363 elements, minus the coating material, were detected at the typical spots for each coupon (i.e.

364 SPEC1, 2, 3) by EDS analysis (Figure 4C, D). The corrosion products, formed in the angular

365 shapes (SPEC 1, Figure 4 C), mainly consisted O, Ca and S with the atomic ratio of 6.3: 0.9:

3661.0 (O: Ca: S). This suggests that the angular crystal corrosion products is mainly gypsum 
$367\left(\mathrm{CaSO}_{4} \cdot 2 \mathrm{H}_{2} \mathrm{O}\right)$, a typical corrosion product in microbial induced concrete corrosion (Grengg 368 et al. 2015, Gutierrez-Padilla and Dolores 2007). Similar to SEM images, the corrosion 369 products were piled up on calcium hydroxide (hexagonal formations) in SPEC 2 and calcium 370 silicate hydrate (a collection of amorphous particles) in SPEC 3 (Figure 4 C), where the 371 calculated atomic ratios were 7.1: 0.8: $1.0(\mathrm{O}: \mathrm{Ca}: \mathrm{S})$ and 10.1: 0.7: 1.0: 0.5 (O: Ca: S: Si), respectively. Although the atomic ratio varied depending on the associated hydration products, the $\mathrm{O} / \mathrm{S}$ ratio, and the soluble sulfur species analysis of the corrosion products collected from each coupon surface, further confirmed that sulfate was the dominant product of the $\mathrm{H}_{2} \mathrm{~S}$ oxidation with some elemental sulfur present in the corrosion product (Figure 4B).

Previously, elemental sulfur was the main product in the initiation stage in laboratory chamber experiments, where it was reported that the abiotic process of concrete corrosion mainly occurred (Jiang et al. 2015b, Joseph et al. 2012). Sulfate was only detected in corrosion products after twelve-month exposure in a laboratory chamber with $50 \mathrm{ppm}$ of gaseous $\mathrm{H}_{2} \mathrm{~S}$ (Jiang et al. 2015b, Joseph et al. 2012). During the initiation stage, the maximum amount of sulfate was reposted as $2.2 \mathrm{~g} \mathrm{~m}^{-2}$ after twelve months exposure, while the levels of elemental sulfur were more than an order of magnitude higher (Joseph et al. 2012). In contrast, the sulfate content of corrosion products on the whole coupon surface in this study were 2-3 times higher than elemental sulfur and were two times higher than the maximum concentration reported in the laboratory chamber study (Joseph et al. 2012) (Figure 4B).

The observed rapid corrosion and the formation of sulfate as the main corrosion products cannot be explained by either the three-stage corrosion development model (Islander et al. 1991) or the previous theory describing the initiation of corrosion (Jiang et al. 2015b, Joseph et al. 2012). The short exposure time suggests that there was likely no development of any sulfide oxidizing microorganisms. Instead, fast chemical oxidation of $\mathrm{H}_{2} \mathrm{~S}$ to sulfuric acid might be the main cause of the observed fast corrosion and sulfate dominated corrosion products. 
393 To delineate the role of microbes in the observed rapid corrosion, the microbial communities

394 were determined for the combined corrosion layer collected from the four coupons (CA, CB)

395 and from wastewater samples (WA, WB) (Figure 5). In the corrosion layer, Bacteroides,

396 Prevotella 9, Barnesiella, Faecalibacterium, Streptococcus, Christensenellaceae R-7 group,

397 and Caulobacter were detected as the top 8 abundant microbes. Most of these bacteria detected

398 are anaerobes and none of them are known to be capable of oxidizing sulfur. Bacteroides

399 Prevotella 9, Barnesiella and Faecalibacterium are obligate anaerobic bacteria, and are found

400 prominently in human guts (Bernhard and Field 2000, Ramirez-Farias et al. 2008, Wu et al.

401 2015). Most Streptococcus are facultative anaerobes and are mostly related to infection of

402 human and animals (Cleary et al. 1992). Firmicutes are anaerobic microbes and found in

403 various environments including human guts and fuel cell experiments (Ismail et al. 2011,

404 Wrighton et al. 2008). Christensenellaceae R-7 group are anaerobic bacteria that can be found

405 in the ruminal mucosa of goats and food waste digester (Jiao et al. 2018, Lee et al. 2017).

406 Caulobacter are generally aerobic microbes detected in a dilute aquatic environments with

407 limiting nutrients (Ely 1991). Based on the probable capabilities of these bacteria detected in

408 the oxidative corrosion layers, there is little to suggest they were active components. It is likely

409 we are detecting the remnants of bacteria that have come from the wastewater. 


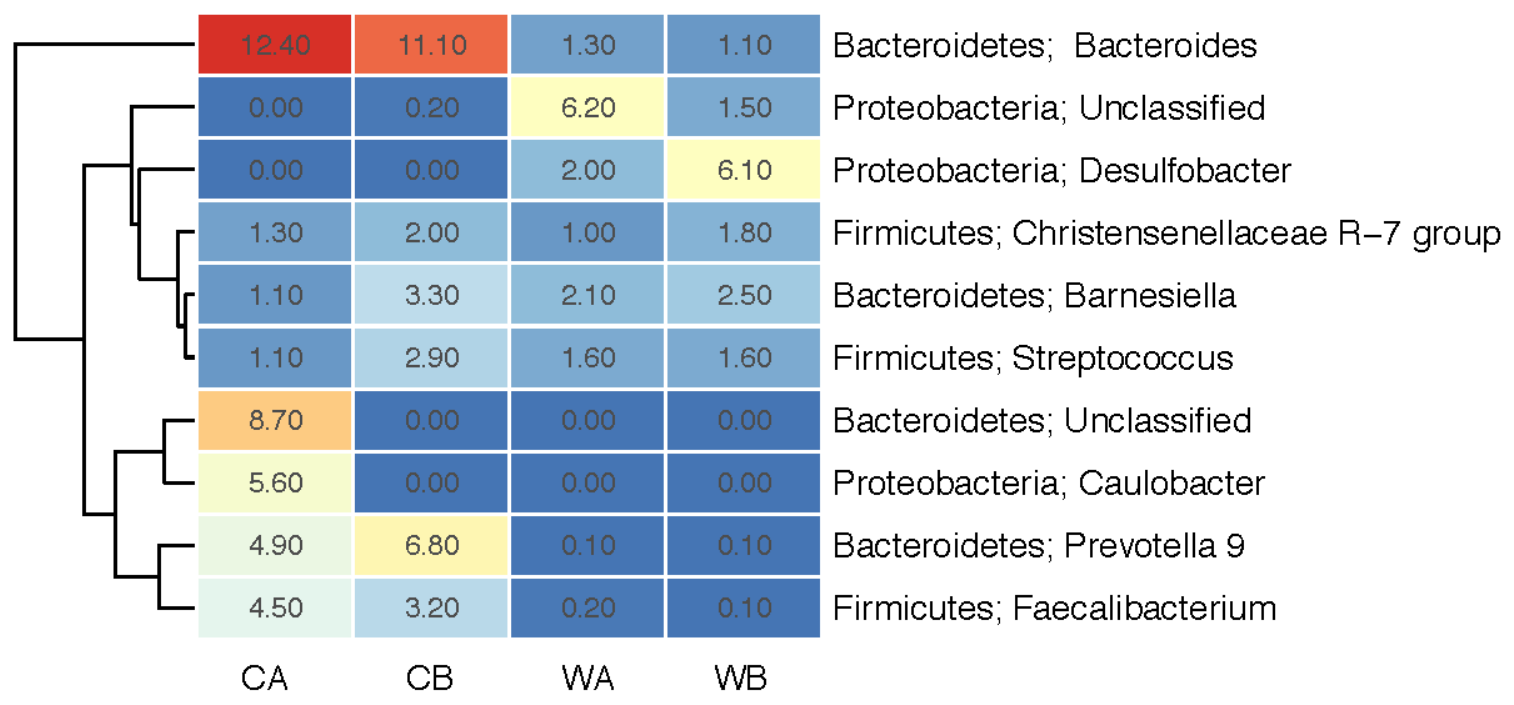

411

412 Figure 5. Heatmap summarizing the percent relative abundances of bacteria (each row representing an

413 OTU) in the corrosion layer samples combined from the four coupons (CA and CB). Two wastewater

414 samples from the same sewer pipe was included as WA and WB. Reads that could not be classified are

415 collectively referred to as 'unclassified'.

416

417 In microbial induced concrete corrosion, once the $\mathrm{pH}$ is reduced to lower than 4 , due to the

418 sulfide oxidation and acid production, acidophilic microbes usually become the dominant

419 species $(>50 \%)$. The most typical genus of acidophilic microorganisms associated with

420 biogenic acid production is Acidithiobacillus including $A$. ferrooxidans, $A$. thiooxidans, and $A$.

421 caldus (Davis et al. 1998, Harrison Jr 1984, Islander et al. 1991, Jiang et al. 2016b, Parker

1945b). In addition to Acidithiobacillus spp., Acidiphilium spp., Mycobacterium spp.,

Xanthomonadales spp, are often detected as abundant in acidophilic communities of sewer

424 corrosion layers (Cayford et al. 2017, Jiang et al. 2016b, Li et al. 2017, Okabe et al. 2007,

425 Pagaling et al. 2014). None of these typical acidophilic sulfur-oxidizing microorganisms was

426 detected in the corrosion products collected from the concrete samples in this study. Therefore,

427 it is highly likely that biological sulfide oxidation was not playing a major role in the rapid

428 corrosion observed in the presence of high $\mathrm{H}_{2} \mathrm{~S}$ levels. 
430 The SOR of the coupons prior to and after sterilization were quite similar for $\mathrm{H}_{2} \mathrm{~S}$ 431 concentrations up to $200 \mathrm{ppm}$ (Figure 6). It shows clearly that sterilization of the concrete did not have any impact on the SOR and it confirms that the microbes on the concrete had negligible role in $\mathrm{H}_{2} \mathrm{~S}$ oxidation. Together with the absence of sulfide oxidizing microbes in 434 the corrosion layer (Section 3.2), it clearly suggests that biological sulfide oxidation is not the cause of the concrete corrosion and thus the SOR observed were mainly due to chemical oxidation of sulfide.
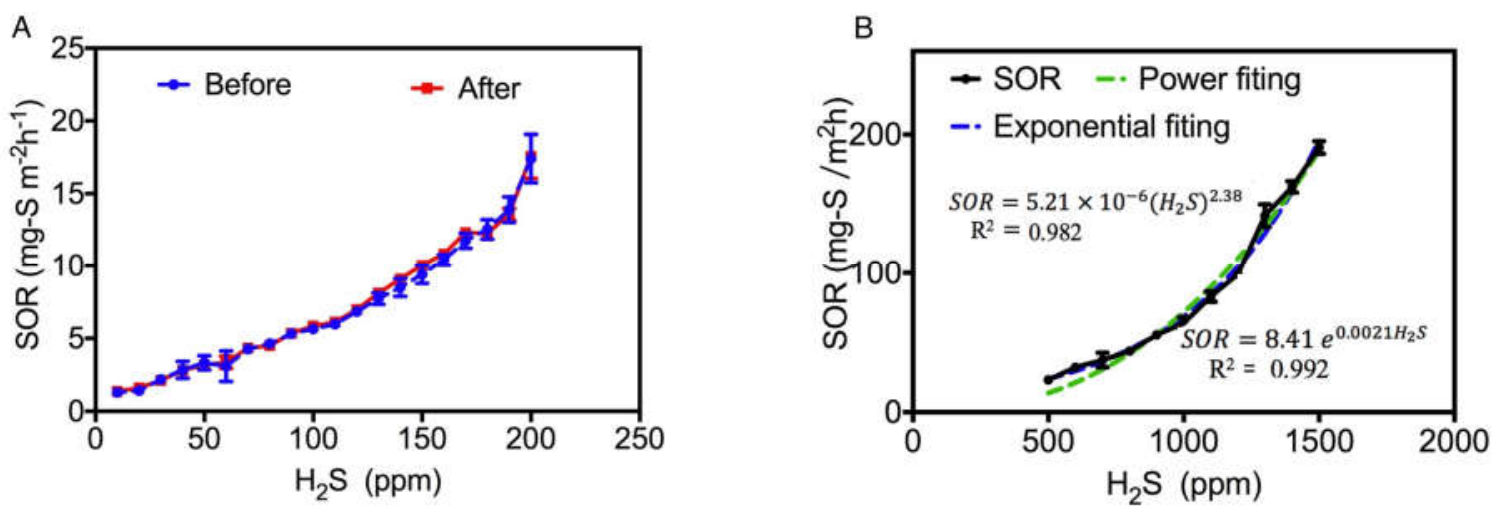

437

Figure 6. Sulfide oxidation rates of concrete coupons before and after sterilization under 10-200 ppm $\mathrm{H}_{2} \mathrm{~S}$ (A), and the sulfide oxidation rates of concrete coupons under 500-1500 ppm $\mathrm{H}_{2} \mathrm{~S}$ (B).

The SOR of both coupons were below $25 \mathrm{mg}-\mathrm{S} \mathrm{m}^{-2} \mathrm{~h}^{-1}$ under 10-200 $\mathrm{ppm}_{2} \mathrm{~S}$ and increased to around $200 \mathrm{mg}-\mathrm{S} \mathrm{m} \mathrm{m}^{-2} \mathrm{~h}^{-1}$ at approximately $1500 \mathrm{ppm}_{2} \mathrm{~S}$. The SOR observed for the chemical oxidation process is comparable to the sulfide uptake rate (SUR). SUR is usually used 444 as a good indicator for the development and activity of sulfide oxidizing bacteria in microbial 445 induced concrete corrosion. The SUR of $250 \pm 5 \mathrm{mg}_{-} \mathrm{S} \mathrm{m}^{-2} \mathrm{~h}^{-1}$ was reported for microbial induced corrosion after 33 months exposure to $\mathrm{H}_{2} \mathrm{~S}$ at $50 \mathrm{ppm}$ (Sun et al. 2014) and around 100

$447 \mathrm{mg}-\mathrm{S} \mathrm{m}^{-2} \mathrm{~h}^{-1}$ for coupons after 17 months exposure under $25 \mathrm{ppm} \mathrm{H}_{2} \mathrm{~S}$ (Jiang et al. 2016b). At 448 the exposure of $1000 \mathrm{ppm}$ of $\mathrm{H}_{2} \mathrm{~S}$, a rapid consumption of $\mathrm{H}_{2} \mathrm{~S}, 3600 \mathrm{mg}^{-\mathrm{S} \mathrm{m}} \mathrm{m}^{-2} \mathrm{~h}^{-1}$ was 
449 observed in a pipe section after several months (Vollertsen et al. 2008). Under the same $\mathrm{H}_{2} \mathrm{~S}$

450 concentration, the SOR measured in this study was relatively lower compared with previous

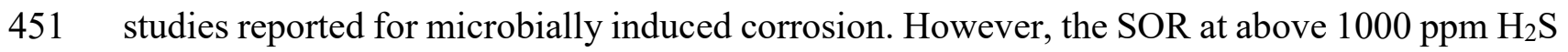

452 of this study were comparable to the uptake rate of microbes under $50 \mathrm{ppm}$ (Sun et al. 2014),

453 which could lead to similar magnitudes of corrosion.

454 Under the high levels of $\mathrm{H}_{2} \mathrm{~S}(500 \mathrm{ppm}-1500 \mathrm{ppm})$, the SOR increased significantly along with

455 the increase of $\mathrm{H}_{2} \mathrm{~S}$ concentration (Figure 6B). Kinetic models (i.e. exponential, power), have

456 been previously used to describe the oxidation rate of sulfide in microbially induced concrete

457 corrosion (Æsøy et al. 2002, Sun et al. 2014). Fitting SOR results into exponential kinetics, the

458 exponent showed a positive value (0.0021) (Figure 6B), which is contrary to the negative value

459 previous reported for microbial corrosion (-0.0135) (Sun et al. 2014). In power kinetic models,

460 the reaction order for sulfide oxidation in this study was estimated to be 2.4 , which is higher

461 than the reaction order (1.5) previously reported for chemical dominated sulfide oxidation on

462 concrete surfaces and also higher than that reported for microbial induced sulfide oxidation on

463 corroding concrete surfaces (0.45-0.7) (Satoh et al. 2009, Vollertsen et al. 2008). With the

464 highest $\mathrm{R}^{2}(0.995)$ and lowest sum of residual squares (323.2), exponential kinetics best

465 described the chemical sulfide oxidation on the concrete surface in this study (Table S2). The

466 kinetic analysis suggested that chemical sulfide oxidation is different to the biological sulfide

467 oxidation and that the SOR increases exponentially with $\mathrm{H}_{2} \mathrm{~S}$ concentration, implicating that

468 chemically induced corrosion will be more severe in sewers with higher $\mathrm{H}_{2} \mathrm{~S}$ concentrations.

\subsection{Chemical oxidation of sulfide in the presence of concrete or corrosion products}

470 In the batch tests with aerated water containing fresh concrete powder, more than $70 \%$ of the

471 sulfide was oxidized within 4 hours (Figure 7A) and the total amount of inorganic sulfur species

472 remained constant (Figure S4). The main oxidation products were found to be sulfate and 
473 thiosulfate, accounting for $52.6 \pm 0.8 \%$ and $42.0 \pm 1.3 \%$ of the total oxidized sulfide, 474 respectively. The molar consumption ratio of sulfide to oxygen was $0.8 \pm 0.1$, which was

480 consistent with the theoretical oxygen demand ratio for the production of sulfate and thiosulfate. During the 4 hour batch tests, the production of elemental sulfur was not observed. The average sulfide oxidation rate was $1.12 \pm 0.01 \mathrm{mg}_{-} \mathrm{S} \mathrm{L}^{-1} \mathrm{~h}^{-1}$ and the $\mathrm{pH}$ was stable at $11.3 \pm 0.1$ during the whole process. This relatively stable $\mathrm{pH}$ is consistent with the strong acid neutralization capacity of concrete powder within the range of $\mathrm{pH}$ 13-10 (Figure S3).
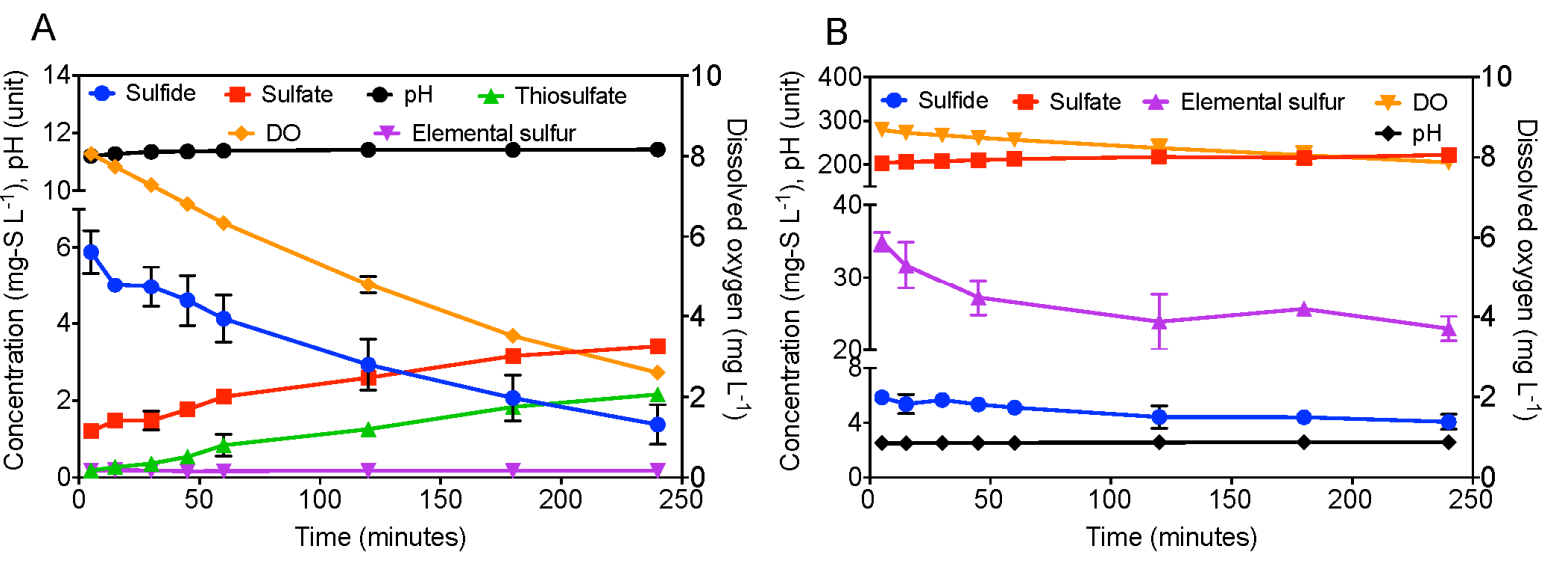

Figure 7. Chemical oxidation of sulfide in aerated water containing fresh concrete powder (A) and autoclaved corrosion layer scrapings (B).

For the batch tests containing autoclaved corrosion layer scrapings, $26 \%$ of the sulfide dosed was oxidized during the tests (Figure 7B). Along with the sulfate production, the elemental sulfur from the corrosion product was reduced by $35 \% \pm 5 \%$. The molar consumption ratio of sulfide/oxygen was $1.7 \pm 0.1$ and the total amount of inorganic sulfur species remained constant. Considering elemental sulfur oxidation and potential formation of polysulfide between elemental sulfur and sulfide, it was unclear whether sulfate production is due to the oxidation of elemental sulfur or sulfide. However, the average sulfide oxidation rate, $0.22 \pm 0.02 \mathrm{mg}^{-\mathrm{S} \mathrm{L}^{-}}$ ${ }^{1} \mathrm{~h}^{-1}$, was 5 times lower than the batch tests with fresh concrete powder. Production of sulfite and thiosulfate was not observed over 4 hours and the $\mathrm{pH}$ was $2.58 \pm 0.09$ during the whole 
493 In previous batch tests, the chemical sulfide oxidation rate in in acidic solutions $(\mathrm{pH}<2)$ of 494 suspended corrosion products was reported as $0.01-0.1 \mathrm{mg}_{-} \mathrm{S} \mathrm{L}^{-1} \mathrm{~h}^{-1}$ and elemental sulfur was assumed to be the main product as deduced from the oxygen and hydrogen sulfide uptake ratio

496 (Jensen et al. 2011). The chemical sulfide oxidation in solutions of crushed new concrete with 497 high alkalinity has not been reported. For the chemical oxidation of sulfide tests in water, 498 thiosulfate is found as the principal product at $\mathrm{pH}>8.5$, regardless of the sulfide/ oxygen ratio, 499 and the oxidation products were not reported at $\mathrm{pH}<6$, since the oxidation rate was very slow 500 (Chen and Morris 1972). In this current study, the production of sulfate by chemical oxidation 501 of sulfide in solutions containing either fresh concrete powder or corrosion product was 502 observed and confirmed by direct measurement for the first time. Possibly the reactions 503 observed here are due to metals such as $\mathrm{Fe}^{2+}, \mathrm{Fe}^{3+}$ and $\mathrm{Cu}^{2+}$, existing in the concrete and corrosion product and catalyzing the chemical oxidation of sulfide. The higher oxidation in fresh concrete solutions suggested more significant impact due to chemical oxidation of sulfide on the concrete corrosion process. Therefore, with sulfuric acid as the main product, chemically

507 induced corrosion of concrete under high $\mathrm{H}_{2} \mathrm{~S}$ concentration in sewers plays a critical role, especially for newly manufactured concrete sewers.

\section{Conclusions}

510 The rapid corrosion of fresh concrete within 20 days at high hydrogen sulfide concentration in 511 sewers was investigated. Different from previous studies, which mainly focus on microbially

512 induced corrosion of concrete sewers, this was the first-ever report of chemically induced 513 corrosion. This has resulted in the following key findings:

514 - Hydrogen sulfide of around $1000 \mathrm{ppm}$ led to fast concrete corrosion within one month, this was characterized by a surface $\mathrm{pH}$ around 3 and a corrosion rate around $3 \mathrm{~mm}^{\text {year }}{ }^{-1}$. 
- The fast corrosion of concrete with high levels of $\mathrm{H}_{2} \mathrm{~S}$ in the sewer was mainly due to the chemical oxidation of hydrogen sulfide to sulfuric acid. No sulfide oxidizing

518 microorganisms were found to participate in the corrosion.

519 - The rate of chemical sulfide oxidation increased exponentially with hydrogen sulfide

520 concentrations and this could induce potentially high corrosion rates.

- These novel findings of in-sewer corrosion processes hold profound implications for sewer operation and corrosion management. The chemically induced corrosion of newly manufactured concrete sewers would be critical when high $\mathrm{H}_{2} \mathrm{~S}$ concentrations occur in the sewer atmosphere, especially at certain corrosion hot spots.

Acknowledgements:

527 The authors acknowledge the financial support provided by the Australian Research Council

528 and the following partners: Gold Coast Water and Waste, District of Columbia Water and

529 Sewer Authority, South East Water for their support through the Australian Research Council

530 Linkage Project LP150101337. Dr Guangming Jiang is the recipient of an Australian Research

531 Council DECRA Fellowship (DE170100694). Xuan Li acknowledges the Chinese Scholarship

532 Council for providing the Living Allowance Scholarship.

533

534

535

536

\section{Reference:}


538 Æsøy, A., Østerhus, S. and Bentzen, G. (2002) Controlled treatment with nitrate in sewers to 539 prevent concrete corrosion. Water Science and Technology: Water Supply 2(4), 137-144.

540 Alexander, M., Bertron, A. and De Belie, N. (2013) Performance of cement-based materials in 541 aggressive aqueous environments, Springer.

542 Australian Standard, A. (1986) 1012.9. Methods for testing concrete.

543 Berndt, M. (2011) Evaluation of coatings, mortars and mix design for protection of concrete 544 against sulphur oxidising bacteria. Construction and Building Materials 25(10), 3893-3902.

545 Bernhard, A.E. and Field, K.G. (2000) A PCR assay to discriminate human and ruminant feces 546 on the basis of host differences in Bacteroides-Prevotella genes encoding 16S rRNA. Applied 547 and Environmental Microbiology 66(10), 4571-4574.

548 Cayford, B.I. (2012) Investigation of the microbial community and processes responsible for the corrosion of concrete in sewer systems, University of Queensland, Brisbane.

550 Cayford, B.I., Jiang, G., Keller, J., Tyson, G. and Bond, P.L. (2017) Comparison of microbial communities across sections of a corroding sewer pipe and the effects of wastewater flooding. Biofouling 33(9), 780-792.

554 Environmental science \& technology 6(6), 529-537.

555 Cleary, P.P., Schlievert, P., Handley, J., Kim, M., Hauser, A., Kaplan, E. and Wlazlo, A. (1992)

556 Clonal basis for resurgence of serious Streptococcus pyogenes disease in the 1980s. The Lancet 557 339(8792), 518-521.

558 Davis, J.L., Nica, D., Shields, K. and Roberts, D.J. (1998) Analysis of concrete from corroded sewer pipe. International Biodeterioration \& Biodegradation 42(1), 75-84.

560 De Muynck, W., De Belie, N. and Verstraete, W. (2009) Effectiveness of admixtures, surface treatments and antimicrobial compounds against biogenic sulfuric acid corrosion of concrete.

562 Cement and Concrete Composites 31(3), 163-170.

563 Ely, B. (1991) Methods in enzymology, pp. 372-384, Elsevier.

564 Franus, W., Panek, R. and Wdowin, M. (2015) SEM investigation of microstructures in 565 hydration products of portland cement, pp. 105-112, Springer.

566 Grengg, C., Mittermayr, F., Baldermann, A., Böttcher, M., Leis, A., Koraimann, G., Grunert, 567 P. and Dietzel, M. (2015) Microbiologically induced concrete corrosion: A case study from a combined sewer network. Cement and Concrete Research 77, 16-25.

569 Gu, J.-D., Ford, T.E., Berke, N.S. and Mitchell, R. (1998) Biodeterioration of concrete by the 570 fungus Fusarium. International Biodeterioration \& Biodegradation 41(2), 101-109.

571 Gutierrez-Padilla, M. and Dolores, G. (2007) Activity of Sulfur Oxidizing Microorganisms and 572 impacts on concrete pipe corrosion, University of Colorado at Boulder.

573 Haaning Nielsen, A., Vollertsen, J. and Hvitved-Jacobsen, T. (2004) Chemical sulfide 574 oxidation of wastewater-effects of $\mathrm{pH}$ and temperature. Water science and technology 50(4), $575 \quad 185-192$.

576 Haile, T. and Nakhla, G. (2010) The inhibitory effect of antimicrobial zeolite on the biofilm of 577 Acidithiobacillus thiooxidans. Biodegradation 21(1), 123-134.

578 Harrison Jr, A.P. (1984) The acidophilic thiobacilli and other acidophilic bacteria that share 579 their habitat. Annual Reviews in Microbiology 38(1), 265-292. 
580 Hvitved-Jacobsen, T., Vollertsen, J. and Nielsen, A.H. (2013) Sewer processes: microbial and 581 chemical process engineering of sewer networks, CRC press.

582 Islander, R.L., Devinny, J.S., Mansfeld, F., Postyn, A. and Shih, H. (1991) Microbial ecology 583 of crown corrosion in sewers. Journal of Environmental Engineering 117(6), 751-770.

584 Ismail, N.A., Ragab, S.H., ElBaky, A.A., Shoeib, A.R., Alhosary, Y. and Fekry, D. (2011) 585 Frequency of Firmicutes and Bacteroidetes in gut microbiota in obese and normal weight 586 Egyptian children and adults. Archives of medical science: AMS 7(3), 501.

587 Jana, D. and Lewis, R.A. (2005) Acid attack in a concrete sewer pipe-a petrographic and 588 chemical investigation.

589 Jensen, H.S., Lens, P.N., Nielsen, J.L., Bester, K., Nielsen, A.H., Hvitved-Jacobsen, T. and 590 Vollertsen, J. (2011) Growth kinetics of hydrogen sulfide oxidizing bacteria in corroded 591 concrete from sewers. Journal of hazardous materials 189(3), 685-691.

592 Jensen, H.S., Nielsen, A.H., Hvitved-Jacobsen, T. and Vollertsen, J. (2009) Modeling of 593 hydrogen sulfide oxidation in concrete corrosion products from sewer pipes. Water 594 Environment Research 81(4), 365-373.

595 Jiang, G., Keller, J. and Bond, P.L. (2014) Determining the long-term effects of $\mathrm{H}_{2} \mathrm{~S}$ 596 concentration, relative humidity and air temperature on concrete sewer corrosion. Water Res $59765,157-169$.

598 Jiang, G., Keller, J., Bond, P.L. and Yuan, Z. (2016a) Predicting concrete corrosion of sewers 599 using artificial neural network. Water Res 92, 52-60.

600 Jiang, G., Melder, D., Keller, J. and Yuan, Z. (2017) Odor emissions from domestic wastewater: 601 A review. Critical Reviews in Environmental Science and Technology 47(17), 1581-1611.

602 Jiang, G., Sharma, K.R., Guisasola, A., Keller, J. and Yuan, Z. (2009) Sulfur transformation in 603 rising main sewers receiving nitrate dosage. Water Research 43(17), 4430-4440.

604 Jiang, G., Sun, J., Sharma, K.R. and Yuan, Z. (2015a) Corrosion and odor management in 605 sewer systems. Current Opinion in Biotechnology 33, 192-197.

606 Jiang, G., Sun, X., Keller, J. and Bond, P.L. (2015b) Identification of controlling factors for 607 the initiation of corrosion of fresh concrete sewers. Water Research 80, 30-40.

608 Jiang, G., Zhou, M., Chiu, T.H., Sun, X., Keller, J. and Bond, P.L. (2016b) Wastewater 609 Enhanced Microbial Corrosion of Concrete Sewers. Environ Sci Technol.

610 Jiao, J., Wu, J., Wang, M., Zhou, C., Zhong, R. and Tan, Z. (2018) Rhubarb supplementation 611 promotes intestinal mucosal innate immune homeostasis through modulating intestinal 612 epithelial microbiota in goat kids. Journal of agricultural and food chemistry 66(4), 1047-1057.

613 Joseph, A.P., Keller, J., Bustamante, H. and Bond, P.L. (2012) Surface neutralization and $\mathrm{H}_{2} \mathrm{~S}$ 614 oxidation at early stages of sewer corrosion: influence of temperature, relative humidity and $615 \mathrm{H}_{2} \mathrm{~S}$ concentration. Water Research 46(13), 4235-4245.

616 Keller-Lehmann, B., Corrie, S., Ravn, R., Yuan, Z. and Keller, J. (2006) Preservation and 617 simultaneous analysis of relevant soluble sulfur species in sewage samples, p. 28.

618 Kutchko, B.G. and Kim, A.G. (2006) Fly ash characterization by SEM-EDS. Fuel 85(17-18), $619 \quad 2537-2544$.

620 Lahav, O., Lu, Y., Shavit, U. and Loewenthal, R.E. (2004) Modeling hydrogen sulfide emission rates in gravity sewage collection systems. Journal of Environmental Engineering 130(11), 1382-1389. 

in full-scale thermophilic and mesophilic anaerobic digesters treating food wastewater: Key process parameters and microbial indicators of process instability. Bioresource technology 245, 689-697.

Li, X., Jiang, G., Kappler, U. and Bond, P. (2017) The ecology of acidophilic microorganisms in the corroding concrete sewer environment. Frontiers in microbiology 8, 683. Microbial corrosion of concrete sewer pipes, H2S production from sediments and determination of corrosion rate. Water science and technology 23(7-9), 1275-1282.

Nica, D., Davis, J.L., Kirby, L., Zuo, G. and Roberts, D.J. (2000) Isolation and characterization of microorganisms involved in the biodeterioration of concrete in sewers. International Biodeterioration \& Biodegradation 46(1), 61-68.

Okabe, S., Odagiri, M., Ito, T. and Satoh, H. (2007) Succession of sulfur-oxidizing bacteria in the microbial community on corroding concrete in sewer systems. Appl Environ Microbiol 73(3), 971-980.

Pagaling, E., Yang, K. and Yan, T. (2014) Pyrosequencing reveals correlations between extremely acidophilic bacterial communities with hydrogen sulphide concentrations, $\mathrm{pH}$ and inert polymer coatings at concrete sewer crown surfaces. J Appl Microbiol 117(1), 50-64.

642

643

Parker, C. (1945a) The corrosion of concrete 2. The function of Thiobacillus concretivorus (nov. spec.) in the corrosion of concrete exposed to atmospheres containing hydrogen sulphide. Australian Journal of Experimental Biology \& Medical Science 23(2).

645 Parker, C.t. (1947) Species of sulphur bacteria associated with the corrosion of concrete. Nature 646 159(4039), 439-440.

647 Ramirez-Farias, C., Slezak, K., Fuller, Z., Duncan, A., Holtrop, G. and Louis, P. (2008) Effect 648 of inulin on the human gut microbiota: stimulation of Bifidobacterium adolescentis and Faecalibacterium prausnitzii. British Journal of Nutrition 101(4), 541-550.

650 Satoh, H., Odagiri, M., Ito, T. and Okabe, S. (2009) Microbial community structures and in 651 situ sulfate-reducing and sulfur-oxidizing activities in biofilms developed on mortar specimens 652 in a corroded sewer system. Water Research 43(18), 4729-4739.

653 Sharma, K.R., Yuan, Z., de Haas, D., Hamilton, G., Corrie, S. and Keller, J. (2008) Dynamics and dynamic modelling of $\mathrm{H}_{2} \mathrm{~S}$ production in sewer systems. Water Research 42(10-11), 25272538 .

657 Distinct microbially induced concrete corrosion at the tidal region of reinforced concrete 658 sewers. Water Research.

659 Song, Y., Wightman, E., Tian, Y., Jack, K., Li, X., Zhong, H., Bond, P.L., Yuan, Z. and Jiang, 660 G. (2018b) Corrosion of reinforcing steel in concrete sewers. Science of the total environment.

661 Standard AS2972, A. 3972. 2010. General Purpose and Blended Cements.

662 Sun, X., Jiang, G., Bond, P.L., Keller, J. and Yuan, Z. (2015) A novel and simple treatment for control of sulfide induced sewer concrete corrosion using free nitrous acid. Water Res 70, 279664 287. 
665 Sun, X., Jiang, G., Bond, P.L., Wells, T. and Keller, J. (2014) A rapid, non-destructive 666 methodology to monitor activity of sulfide-induced corrosion of concrete based on H 2 S 667 uptake rate. Water Research 59, 229-238.

668 Vollertsen, J., Nielsen, A.H., Jensen, H.S., Wium-Andersen, T. and Hvitved-Jacobsen, T. 669 (2008) Corrosion of concrete sewers - the kinetics of hydrogen sulfide oxidation. Science of 670 the total environment 394(1), 162-170.

671 Wells, T. and Melchers, R.E. (2015) Modelling concrete deterioration in sewers using theory 672 and field observations. Cement and Concrete Research 77, 82-96.

673 Wells, T., Melchers, R.E. and Bond, P. (2009) Factors involved in the long term corrosion of 674 concrete sewers. Australasian corrosion association proceedings of corrosion and prevention, 675 Coffs Harbour, Australia 11.

676 Wrighton, K.C., Agbo, P., Warnecke, F., Weber, K.A., Brodie, E.L., DeSantis, T.Z., 677 Hugenholtz, P., Andersen, G.L. and Coates, J.D. (2008) A novel ecological role of the 678 Firmicutes identified in thermophilic microbial fuel cells. The ISME journal 2(11), 1146.

679 Wu, M., McNulty, N.P., Rodionov, D.A., Khoroshkin, M.S., Griffin, N.W., Cheng, J., Latreille, 680 P., Kerstetter, R.A., Terrapon, N. and Henrissat, B. (2015) Genetic determinants of in vivo 681 fitness and diet responsiveness in multiple human gut Bacteroides. Science 350(6256), 682 aac5992.

683 Zhang, L., De Schryver, P., De Gusseme, B., De Muynck, W., Boon, N. and Verstraete, W. 684 (2008) Chemical and biological technologies for hydrogen sulfide emission control in sewer 685 systems: A review. Water Research 42(1-2), 1-12. 